\title{
THE EFFECT OF STAKEHOLDERS ON VILLAGE COMMUNITY CREATIVITY AND COMMUNITY WELFARE OF COASTAL VILLAGE IN THE BALI PROVINCE, INDONESIA
}

\author{
Jayawibawa Ketut Ngurah Boy*, Doctoral Candidate \\ Setiawina Nyoman Djinar, Professor \\ Dewi Made Henny Urmila, Marhaeni A.A. I. N., Lecturers \\ Faculty of Economics and Business, University of Udayana, Denpasar, Bali, Indonesia \\ *E-mail: bjw889@gmail.com
}

\begin{abstract}
Human development in Bali continues to progress, but there are still complicated problems, namely the economic equality of Bali. The acceleration of rural development is a step taken by the government at this time both at the national and regional levels. To that end, as an option that is expected to be taken is the development of new attractions in the area of Bali, including the development of coastal tourism along the coast of the island of Bali. The purpose of this study was to analyze the influence of the role of the stakeholders (central and local government, local village) on strengthening the economic efforts of the people and the welfare of the village community through the creativity of the village community and the development of village tourism in the coastal tourism village of Bali Province. The sample of this research area was determined by purposive sampling (16 sample villages), while the respondent population were stakeholders in the coastal village area (192 respondents). Data collected through questionnaires and was analyzed using descriptive analysis and inferential analysis (path diagram, multiple linear regression arranged in the form of structural equation models (SEM). The results stated that the role of the central government had the most positive and significant influence on the creativity of village communities, the development of village tourism, and the strengthening of people's economic efforts. Whereas the positive and significant direct effect on the welfare of village communities is the strengthening of democratic economic endeavors.
\end{abstract}

\section{KEY WORDS}

Stakeholders, creativity, village community, development, village tourism, people economic enterprises, community welfare, coastal tourism village.

Bali's economic growth is very dependent on tourism. Ironically, tourism built based Balinese culture and supported by the whole community, it produces income inequality between people, between areas. To resolve the issue of the Government run the program development village.

Rural tourism development according to Cawley and Gillmor (2008) should utilize a variety of resources that exist, namely; the resources of public, private and other stakeholders, and is inherently includes the potential negative impact upon the possibility of the use of natural resources, cultural and social building In creating an atmosphere conducive of rural tourism development required synergies between stakeholders consisting of local community, Government and private, with the function and role of each.

Rahayu et al. (2015) explained the results of his research that the scope of the CBRT (community-based rural tourism) is very wide, so it is necessary to involve multi dimensional input, and many stakeholders (with various interests). The beauty of nature (including) the island of Bali and a unique community culture made popular by the tourist island of Bali. Development of coastal tourism in many countries has proven to be able to resurrect the economy of a society in its territory.

Rural tourism is one of the social forms of tourism that is now driven by the government, in order to diversify the source of community income and maintain the environment. Bengi E. and Gülşen K. (2012) stating the involvement and active participation of citizens in the process of rural tourism development seems to be a prerequisite to 
achieving the objectives of sustainability, and thereby improving the well-being Overall in the community. The concept of village community creativity can be proved beneficial for the development of sustainable and rural endogenous rural regeneration (Escalona-Orcao et al., 2016).

Human development in Bali continued to progress, but still there is a strange problem namely equitable economy. The acceleration of rural development is a step taken Government currently presents either national or regional. To that end, as an option which is expected to be taken is to the development of new attractions that exist in the area of Bali, among others, the development of coastal tourism along the coastal region of the island of Bali.

The purpose of this study was to analyze the influence of the role of the Central Government, local governments, and private local villages against the strengthening of business people's economy and the well-being of the community of the village through village communities and the development of creativity tourist villages on the coast of the province of Bali.

\section{THEORETICAL REVIEW}

According to United Nations in the Report of the World Commission on Environment and Development, Our Common Future (1987), stating that sustainable development as a process of development (land, cities, businesses, communities, and so on) that principled "meet the needs of the present without compromising the fulfilment of the needs of future generations ". One of the factors that must be faced in order to achieve sustainable development is how to improve the environmental devastation without sacrificing the needs of economic development and social justice (Soubbotina, 2004).

Some thoughts on sustainable development which the drafter is summed up by the Gondokusumo (2005), where the mentioned requirements need to be met to achieve the process of sustainable development. These terms are generally divided into three major indicators, namely: (1) pro welfare economics; (2) continuous surroundings pro; and (3) the pros of social justice.

UNWTO (2013) stated that tourism that takes full account of its current and future economic, social and environmental impacts, addressing the needs of visitors, the industry, the envirionment and host communities. Thus in the concept of sustainable tourism development is the focus lies in two things, namely the sustainability of tourism as an economic activity on the one hand, and the other side consider tourism as an element of development policy sustainable.

The basic principle of sustainable tourism development should refer to the basic principles of sustainable development. According to Aronsson (2000) conveys some principal thoughts on sustainable development of tourism interpretation, namely: (i) were able to overcome the problems of trash the environment and ecological perspective, (ii) shows partiality on the construction of small-scale and local community-based/local, (iii) put the tourist destination as the recipient of the benefits of tourism and to achieve it should not by exploiting the local area, (iv) emphasis on cultural sustainability and this relates to development efforts and maintain a traditional building, cultural relics in the tourist destination.

The basic principle of sustainable tourism development should refer to the basic principles of sustainable development. According to Aronsson (2000) conveys some principal thoughts on sustainable development of tourism interpretation, namely: (i) were able to overcome the problems of trash the environment and ecological perspective, (ii) shows partiality on the construction of small-scale and local community-based/local, (iii) put the tourist destination as the recipient of the benefits of tourism and to achieve it should not by exploiting the local area, (iii) emphasis on cultural sustainability and this relates to development efforts and maintain a traditional building, cultural relics in the tourist destination. 
As the industry trade services, tourism activities is inseparable from the role of Government as well as the Central Government or local governments. The Government is responsible for four major things namely; Planning (planning) the area or the area of tourism, development (development) and supporting facilities, tourism spending policy (policy) tourism, and the making and enforcement of regulations (regulations).

Regional autonomy has opened up opportunities for local governments to develop a prudent policy on the premises, including in cooperation with private parties, or known as the Public Private Partnership (PPP). There are three things that encourage governments to do government and private cooperation, namely due to issues of limited funds, efficiency and effectiveness of government, and government accountability to the public. Therefore, there is a need for cooperation between the Government and the private sector and local communities for the improvement of creativity and innovation in the development and management of tourism potentials, and cooperate to provide counseling about Local cultural enhancements.

According to Henocque \& Tandavanitj (2008) in coastal management, the private sector has an important role in achieving effective and integrated coastal management. Similarly, research from Sharif and Lonik (2017) stated that employers played an important role in maintaining rural tourism and the formulation of sustainable strategies to be the founder of tourism business and local development machinery.

Scherl and Edwards (2007) described the local community as follows, a group of people with a common identity and who may be involved in a series of aspects related to livelihoods. They further noted that local communities often have indigenous rights associated with their natural areas and resources and strong relationships with areas that are culturally, socially, economically and spiritually. According to Aref et al. (2010), the community refers to a group of individuals living or working in the same geographic region as a culture or common interest. This community's geographical definition is important to understand how community development is related (Olsder and Van der Donk, 2006) or community's ability to improve tourism development. The findings of Muganda et al. (2010) revealed that local communities want to be involved when tourism policy is created to enable policymakers to set up policies that meet stakeholder needs and address concerns Their. The advantages gained by local communities from sustainable tourism, are: through economic development, job creation, and infrastructure development.

Rural tourism can be defined simply as tourism that takes place in a rural context; Or as an economic activity that relies on, and exploits, the countryside. According to Weaver (1986) Rural tourism can increase job opportunities, increase revenues, solidify the domestic economic foundation, but can also increase cultural opportunities for the people of the forging. Javan and Saghayi (2004) for villages with limited development options can consider tourism as a panacea for their growth and development. Tayebi et al. (2008) advises in developing rural tourism, the stipulated strategy must be in accordance with the objectives, manners, customs and local traditions of the area and in accordance with local regulations and regulations.

Tourist activities are considered beach tourism activities when based or utilizing coastal or sea resources, whether natural or man-made or located within the coastline (Tanzania Coastal Management Partnership Support Unit Coastal Tourism Working Group, 2001). Tourism literature has demonstrated the possible benefits of coastal tourism to the economy, community, and environment also has highlighted issues and challenges relating to the development of coastal tourism. Positive benefits are often mentioned focus on generation of income, job creation and local welfare, infrastructure and community facilities, awareness of conservation needs, investments in the environment and cultural heritage, and contributions to sustainable community livelihoods.

According to Rastghalam et al. (2017) is a sustainable space that creates a platform for the attractiveness and development of creative classes in the industry with low-level technology, especially in the fields of culture and art. The five main elements of creative village are consist from: rural communities, activities, economic activities, village environment, social cohesion and relationships and vision. 
Rastghalam et al. (2017) also pointed out there are five creative indicators of the village, namely: flexibility and acceptance, innovation, taking risks, leadership and participation. Each of them is as follows: (i) flexibility and acceptance. Creative village is not stuck in the past. Flexibility and innovation provide context for sustainable development, (ii) innovation. Creative villages can utilize innovative solutions to solve problems and to achieve goals, (iii) risk taking. The capacity to take risks is characteristic of community members in Creative village. Willingness to take risks has a direct relationship with the advent of innovation, (iv) leadership. Leadership can influence individuals and guide them towards a specific target, including creativity-oriented, (v) participation. In the village's creative concept, ideas, participation, show that villagers engage in social, economic, political activities that enhance social cohesion.

According to Mubyarto (1999) The People's economy is an economic system that is operationalized through the outsourcing and full protection of the economic sector of the people. The main characteristic of the people's economy is the subsistence and with the main capital of family Labor with its capital and technology of Inexistence (Mubyarto, 1999). The role of state in the nation's economic system, among others, includes five things as follows: (i) developing cooperatives (ii) developing SOES; (iii) To ensure the utilization of the Earth, water, and all the wealth contained therein for the magnitude of the prosperity of the people; (iv) fulfill the right of every citizen to obtain a proper employment and livelihood; (v) to maintain poor and neglected children.

In addition to the size of this GRDP there are still other measures used measuring the welfare of the general public, namely HDI (Human Development Index). IPM is expressed as a measure of the welfare of the wider community because, able to describe the achievement in the Community welfare sector in the aggregate, considering that this index including all developments in the economic sector and also the social-cultural sector At once. Welfare not only through economic perspectives as commonly recorded in gross Regional domestic product (GRDP) per capita, but also applied through the access of social sector, namely the health and wellness. In the last case, the literacy rate and the level of Living Hope are two indicators that are commonly listed in the construction of HDI (BAPPEDA of Bogor City, 2018).

\section{RESEARCH FRAMEWORK AND HYPOTHESES}

The conceptual framework on this research was built on logical relationship of the foundations and empirical studies that have been described in the literature review.

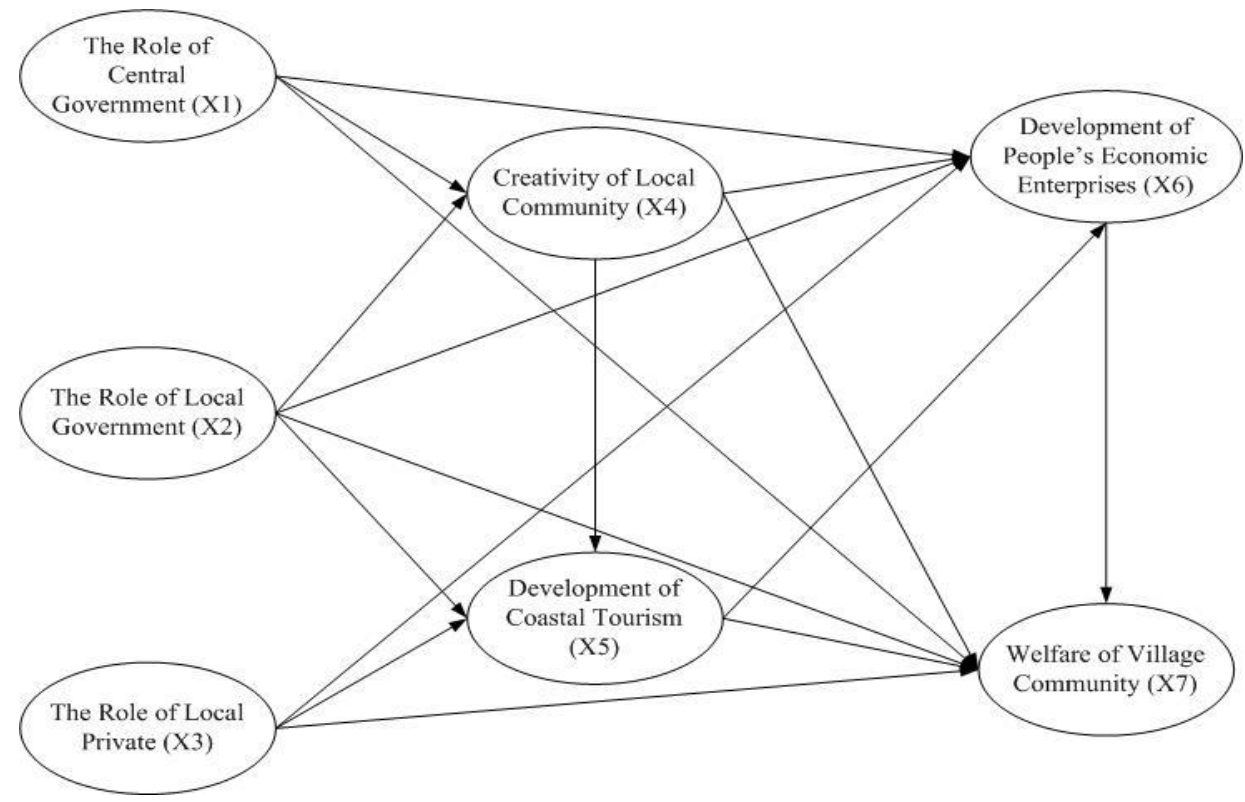

Figure 1 - Conceptual Framework 
Based on the conceptual framework, two research hypotheses can be prepared:

- The central government, local governments, and private locales, have a positive influence on the creativity of the village;

- The role of central government, local government, private premises and village creativity, influence on the development of coastal tourism;

- The role of central government, local governments, private locales, the creativity of village communities and the development of coastal tourism, has an effect on the development of the economic business;

- The role of central government, local governments, private locales, the creativity of village communities, the development of coastal tourism and the development of the Community's economic efforts, affect the welfare of village communities.

\section{METHODS OF RESEARCH}

This research is a quantitative approach that features a qualitative technique to complement the interpretation of the research results. The sample of this research area is determined by purposive sampling as many as 16 sample villages, while the respondents population is a stakeholder in the coastal village area, with samples of 192 respondents as well as purposive sampling.

This research is a quantitative approach that features a qualitative technique to complement the interpretation of the research results. The sample of this research area is determined by purposive sampling as many as 16 sample villages, while the respondents population is a stakeholder in the coastal village area, with samples of 192 respondents as well as purposive sampling.

The variable relationship in the path chart (Fig 1.) can be compiled according to the following equation.

Direct connection between variables:

$$
\begin{gathered}
X 4=\alpha 1 X 1+\alpha 2 X 2+\alpha 3 X 3+\varepsilon 1 \\
X 5=\beta 1 X 1+\beta 2 X 2+\beta 3 X 3+\beta 4 X 4+\varepsilon 2 \\
X 6=Y 1 X 1+Y 2 X 2+\beta 3 X 3+Y X 4+Y 5 X 5+\varepsilon 3 \\
X 7=\delta 1 X 1+\delta 2 X 2+\delta 3 X 3+\delta 4 X 4+\delta 5 X 5+\delta 6 X 6+\varepsilon 4
\end{gathered}
$$

Indirect connection between variables:

$$
\begin{gathered}
X 5=\lambda 1(X 1 X 4)+\lambda 2(X 2 X 4)+\lambda 3(X 3 X 4)+\varepsilon 5 \\
Y 6=v 1(Y 1 Y 5)+v 2(Y 2 Y 5)+v 3(Y 3 Y 5)+v 4(Y 4 Y 5)+\varepsilon 6 \\
Y 7=\pi 1(Y 1 Y 4 Y 6)+\pi 2(Y 2 Y 4 Y 6)+\pi 3(Y 3 Y 46)+\varepsilon 7
\end{gathered}
$$

Where:

$\mathrm{X} 1=$ the role of central government;

$\mathrm{X} 2$ = the role of local government (province/regency/city);

$\mathrm{X} 3=$ the role of local private;

$\mathrm{X} 4=$ creativity of local community;

$\mathrm{X} 5=$ development of coastal tourism;

$\mathrm{X} 6$ = development of people's economic enterprises;

$\mathrm{X} 7=$ welfare of village community.

\section{RESULTS OF STUDY}

According to Tenenhaus et al. (2005) in the line PLS model, there are two subjects that need to be displayed, namely: (1) outer model, which is a measurement model that connects variables that can be observed with the variables; and (2) inner model, ie the structural model that connects some of the latent variables of endogenous with other latent variables. 
The evaluation of the model that applies here is the validity and reliability test for models that use a reflective variable entirely. The reliability of the indicator aims to assess whether or not a latent variable measurement indicator is reliable. Reliability of each variable (factor loadings) is assessed according to the available sizes, namely: measurements according to Fornell and Larcker (1981), measurements according to Cronbach's (1951) Alpha, and measurement of composite reliability. In general, models on this study have fulfilled the criteria of the outer model evaluation, although the results of the composite reliability evaluation showed less reliable $\mathrm{X} 3$ variables, but on the other tests $\mathrm{X} 3$ variables meet the criteria, so it remains retained on the model.

The coefficient of determination $\left(R^{2}\right)$ is a way of assessing how large a variable endogenous construction can be explained by an exogenous construct. Data analysis results using bootstrapping management indicate the value of the $R^{2}$ as Table 1.

Table 1 - R-Square Model

\begin{tabular}{|c|c|c|c|}
\hline Variable & R-Square & R-Square Adjusted & Result \\
\hline X4 (creativity of local community) & 0.116 & 0.087 & Weak \\
\hline X5 (development of coastal tourism) & 0.283 & 0.251 & Moderat \\
\hline X6 (development of people's economic enterprises) & 0.321 & 0.284 & Moderat \\
\hline X7 (welfare of village community) & 0.258 & 0.208 & Moderat \\
\hline
\end{tabular}

The result of the analysis of the coefficient of determination in table 1 can be explained as follows: (1) variable $\mathrm{X} 4$ (Creative village community) is relatively weak in determining variations in changes to the model; (2) Variable X5 (coastal tourism development). X6 (Strengthening the economic business of the Community) and $\mathrm{X} 7$ (the welfare of village communities) is relatively moderate, in determining variations in changes to the model.

In PLS two types of statistics Q-square is estimated using the Blindfold calculation method, which is cross-validality communality $(\mathrm{H} 2)$ and cross-validated redundancy $(\mathrm{F} 2)$ as shown in table 2.

Table 2 - Q-Square Model

\begin{tabular}{|c|c|c|c|c|c|c|}
\hline \multirow{2}{*}{ Variable } & \multicolumn{3}{|c|}{ Q-Square $(\mathrm{H} 2)$} & \multicolumn{3}{|c|}{ Q-Square (F2) } \\
\hline & SSO & SSE & Q-Square $=1-S S E / S S Q$ & SSO & SSE & Q-Square $=1-S S E / S S Q$ \\
\hline $\mathrm{X} 1$ & 288.000 & 233.157 & 0.190 & 288.000 & 288.000 & 0.000 \\
\hline $\mathrm{X} 2$ & 288.000 & 202.599 & 0.297 & 288.000 & 288.000 & 0.000 \\
\hline $\mathrm{X} 3$ & 288.000 & 282.711 & 0.018 & 288.000 & 288.000 & 0.000 \\
\hline $\mathrm{X} 4$ & 288.000 & 230.302 & 0.200 & 288.000 & 274.030 & 0.049 \\
\hline $\mathrm{X} 5$ & 288.000 & 202.656 & 0.296 & 288.000 & 244.182 & 0.152 \\
\hline $\mathrm{X} 6$ & 288.000 & 226.974 & 0.212 & 288.000 & 261.181 & 0.093 \\
\hline $\mathrm{X} 7$ & 288.000 & 209.315 & 0.273 & 288.000 & 253.946 & 0.118 \\
\hline
\end{tabular}

Where: $X 1=$ the role of central government; $X 2=$ the role of local government (province/regency/city); $X 3=$ the role of local private; $X 4=$ creativity of local community; $X 5$ = development of coastal tourism; $X 6=$ development of people's economic enterprises; $X 7=$ welfare of village community.

Table 2 shows that the model used is accurate, because it has a value of $Q$-square construct crossvalidated communality total that is greater than $0(\mathrm{Q} 2>0)$.

The effect size or $\mathrm{F}$ - square is a measurement of the magnitude between variables. Results of the $\mathrm{F}$ - square analysis using Bootstrapping processing show results, such as the data presented in Table 3.

Measuring the path coefficient between the compound to see the signment and the strength of the relationship is also to test the hypothesis. The coefficient path value ranges from- 1 to 1 . The closer the value is 1 , the relationship to the two construction is stronger. A closer relationship-1 indicates that the relationship is negative. (Sarstedt et al, 2017). The result of Path Coefficient analysis using Bootstrapping processing indicates that there are four connections between the latent variables that are significant as in Table 4. 
Table 3 - F-Square

\begin{tabular}{|c|c|c|c|c|}
\hline Variable & $\begin{array}{c}\text { X4 (creativity } \\
\text { of local community) }\end{array}$ & $\begin{array}{c}\text { X5 (development } \\
\text { of coastal tourism) }\end{array}$ & $\begin{array}{c}\text { X6 (development } \\
\text { of people's economic } \\
\text { enterprises) }\end{array}$ & $\begin{array}{c}\text { X7 (welfare } \\
\text { of village } \\
\text { community) }\end{array}$ \\
\hline $\begin{array}{c}\text { X1 (the role of central } \\
\text { government) }\end{array}$ & 0.042 & 0.080 & 0.028 & 0.021 \\
\hline $\begin{array}{c}\text { X2 (the role of local } \\
\text { government) }\end{array}$ & 0.019 & 0.003 & 0.003 & 0.003 \\
\hline $\begin{array}{c}\text { X3 (the role of local } \\
\text { private) }\end{array}$ & 0.017 & 0.025 & 0.005 & 0.007 \\
\hline $\begin{array}{c}\text { X4 (creativity of local } \\
\text { community) }\end{array}$ & 0.118 & 0.000 & 0.041 \\
\hline $\begin{array}{c}\text { X5 (development of coastal } \\
\text { tourism) }\end{array}$ & & 0.199 & 0.023 \\
\hline $\begin{array}{c}\text { X6 (development of } \\
\text { people's economic } \\
\text { enterprises) }\end{array}$ & & & & 0.028 \\
\hline
\end{tabular}

Table 4 - Path Coefficient

\begin{tabular}{|c|c|c|c|c|c|c|}
\hline Variable & $\begin{array}{c}\text { Original Sample } \\
(\mathrm{O})\end{array}$ & $\begin{array}{c}\text { Sample Mean } \\
(\mathrm{M})\end{array}$ & $\begin{array}{c}\text { Standard Deviation } \\
(\text { Stdv })\end{array}$ & $\begin{array}{c}\text { T Statistics } \\
(\mathrm{O} / \text { Stdv })\end{array}$ & $\begin{array}{c}\text { p- } \\
\text { Values }\end{array}$ & $\begin{array}{c}\text { Result } \\
\text { X1 X5 }\end{array}$ \\
0.278 & 0.279 & 0.125 & 2.231 & 0.026 & Significant \\
\hline $\mathrm{X} 4 \rightarrow \mathrm{X} 5$ & 0.310 & 0.307 & 0.082 & 3.777 & 0.000 & Significant \\
\hline $\mathrm{X} 4 \rightarrow \mathrm{X} 7$ & 0.196 & 0.208 & 0.006 & 2.280 & 0.023 & Significant \\
\hline $\mathrm{X} 5 \rightarrow \mathrm{X} 6$ & 0.433 & 0.436 & 0.100 & 4.344 & 0.000 & Significant \\
\hline
\end{tabular}

Where: $X 1=$ the role of central government; $X 2=$ the role of local government (province/regency/city); $X 3=$ the role of local private; $X 4=$ creativity of local community; $X 5=$ development of coastal tourism; $X 6=$ development of people's economic enterprises; $X 7=$ welfare of village community.

In table 4 results analysis of the line coefficient test is seen there are four (4) connections between significant latent variables. The relationship of latent variables can be explained as follows:

- X1 (central government role) has significantly positive effect on the X5 (coastal tourism development). The role of central government through allocation of village funds is able to encourage the village in coastal tourism development;

- X4 (the creativity of the village community) significantly affects the X5 (coastal tourism development). The creativity of the growing village community is capable of encouraging the village in coastal tourism development;

- X4 (the creativity of the village community) significantly affected by the X7 (village community Welfare). The creativity of the village community is increasing to increase Kesejahteraaan village community;

- X5 (coastal tourism development) significantly positively affects the X6 (strengthening of the business economy). The development of coastal tourism is able to encourage efforts to strengthen the economic business.

Indirect effect measurement aims to see the power of variable relationship mediator with other variables in the line diagram model. Indirect influence differentiated two parts, namely total indirect effects and specifict indiret effect. The indirect effect of the relationship is significant as shown in Table 5.

Table 5 - Indirect Effect

\begin{tabular}{|c|c|c|c|c|}
\hline \multicolumn{5}{|c|}{ Total Indirect Effect } \\
\hline Variable & Original Sample (O) & T-Statistics (O/Stdv) & T-table ( $\alpha$ 5\%) & Result \\
\hline $\mathrm{X} 1 \rightarrow \mathrm{X} 6$ & 0.154 & 2.337 & 1.984 & Significant \\
\hline $\mathrm{X} 1 \rightarrow \mathrm{X} 7$ & 0.157 & 2.356 & 1.984 & Significant \\
\hline $\mathrm{X} 4 \rightarrow \mathrm{X} 6$ & 0.134 & 2.838 & 1.984 & Significant \\
\hline \multicolumn{5}{|c|}{ Specific Indirect Effect } \\
\hline $\mathrm{X} 1 \rightarrow \mathrm{X} 5 \rightarrow \mathrm{X} 6$ & 0.134 & 2.838 & 1.984 & Significant \\
\hline $\mathrm{X} 4 \rightarrow \mathrm{X} 5 \rightarrow \mathrm{X} 6$ & 0.121 & 2.028 & 1.984 & Significant \\
\hline
\end{tabular}

Where: $X 1=$ the role of central government; $X 2=$ the role of local government (province/regency/city); $X 3=$ the role of local private; $X 4=$ creativity of local community; $X 5=$ development of coastal tourism; $X 6=$ development of people's economic enterprises; $X 7=$ welfare of village community. 


\section{DISCUSSION OF RESULTS}

The data analysis model that was applied was good to use as a tool estimation Degan using structural model by involving as many as seven latent variables (the construct) and as many as twenty-one variable indicator of the Konstruk.

The research hypothesis test results related to steakholders role consist of each stakeholder, namely: central government, local government, private premises and village community show results, as follows.

The significant direct influence of the role of the central government is revealed through the creativity of village communities, the development of coastal tourism and the strengthening of the Community's economic efforts. Meanwhile, the direct influence of the role of the central government has not shown significant results in increasing the welfare of the coastal village community.

The total influence of the central government's role in the welfare of village communities based on the results of the discussion shows the highest position compared to other variables. Indirect influence of the role of the central government of the Terngkap, through:

- Mediation of village community creativity, the role of central government indicates there is a significant influence on the development of coastal tourism;

- Mediation of creativity in village community and coastal tourism development, the role of the central government indicates that there is a significant influence on the strengthening of the economic business of the community;

- Mediation of village community creativity, the role of central government there is a significant influence on the welfare of village community.

The partial influence of the central government's role is revealed significantly, through the allocation of village funds that it serves to the development of village infrastructure such as village roads and other village facilities according to the needs of local villages, community empowerment, and Preservation of Customs, culture and the village environment.

The direct influence of local government's role is revealed through the results of the discussion is significant through the creativity of village community. Meanwhile, direct influence the role of local governments have not been significant in the development of coastal tourism and strengthening the economic business of the Community and the welfare of coastal village communities.

The total influence of the local government's role is revealed from the results of the discussion, indicating a positive effect on the welfare of the village community, but the influence is still lower than the central government.

Indirect influence of the role of local government revealed through the results of discussion, namely no significant influence through the creativity of the village community, the development of coastal tourism, strengthening the economic business and welfare of the community Village.

The partial influence of the local government's role revealed significantly through the financial aid of Khuus village which is intended for the development of village infrastructure such as village roads and other village facilities according to the needs of local villages, then Village community Empowerment and preservation of indigenous, cultural and rural environment.

The direct influence of the local private role revealed through the results of the discussion is not yet demonstrated significant results to the creativity of the village community, the development of coastal tourism, strengthening the economic efforts of the Community and the welfare of village communities Beach.

The total influence of the local private role revealed through the results of the discussion is not positive towards improving the welfare efforts of the village community.

The indirect influence of the local swata role is revealed through the results, is no significant influence on the creativity of the village community, the development of coastal 
tourism, strengthening the economic business of wealth and welfare of the village community.

The partial influence of the local private is revealed to be insignificant in the construction of village infrastructure - village roads and other means, and the preservation of existing, cultural and rural environments. However, the local private role seemed to have a significant effect on empowering village communities.

The direct influence of local community creativity is revealed through the results of the discussion, it is significant to the development of coastal tourism and also to the welfare of village communities in coastal villages. Then the direct influence of local community creativity shows no significance to the welfare of the village community in the coastal village.

Total influence from the creativity of the village community is revealed from the results of the discussion, indicating a positive effect on the welfare of the village community, and its influence is still lower than the central government.

Indirect influence of the local private role was revealed through the results of the discussion, namely through the mediation of coastal tourism development showed no significant influence on strengthening the economic business of wealth and welfare of village community.

The partial influence of village community creativity revealed significantly through; Creative and innovative in the development of coastal tourism, creative and innovative in strengthening the socio-economic business, and creative and innovative in the preservation of the customs-culture and the village environment.

\section{CONCLUSION AND IMPLICATIONS}

Data analysis results show that the development of coastal tourism is significantly influenced by the role of central government and local community creativity. The development of the company's economic efforts is significantly influenced by the development of coastal tourism, while the welfare of the village community is significantly influenced by the creativity of local communities.

There are a number of things suggested as follow-up results, is that the central government needs to strengthen its role as well as directing local governments, private locales as well as local communities to more actively develop coastal tourism in Bali. In addition it takes a real effort to develop the creativity of local communities so that it can become a major capital strengthening the welfare of village communities.

\section{REFERENCES}

1. Aref, F., Gill, S. S., and Aref, F. (2010). Tourism Development in Local Communities: As a Community Development Approach. Journal of American Science, Vol. 6, No. 2, 155 161.

2. Aronsson, L. (2000). The Development of Sustainable Tourism. London: Continum.

3. BAPPEDA Kota Bogor. (2018). Indikator Kesejahteraan Umum. Bogor: BAPPEDA Kota Bogor.

4. Bengi, E. \& Kirbas, G. (2012). Local Community Involvement in Rural Tourism Development: The Case of Kastamonu, Turkey. Pasos. Revista de Turismo y Patrimonio Cultural, Vol. 10, No. 2, 17-24.

5. Cawley, M. \& Gillmor, D. A. (2008). Integrated Rural Tourism: Concepts and Practice. Annals of Tourism Research, Vol. 35, No. 2, 316-337.

6. Cronbach, L. J. (1951). Coefficient Alpha and The Internal Structure of Tests. Psychometrika, Vol. 16, 297-334.

7. Escalona-Orcao, A. I., Saez-Perez, L. A. \& Valverde-Garcia, B. S. (2018). Location Conditions for the Clustering of Creativite Activities in Extra-Metropolitan Areas: Analysis and Evidence from Spain. Applied Geography, Vol. 91, 1-9.

8. Gondokusumo, A. A. (2005). Komunikasi Penugasan. Cetakan Kelima. Jakarta: Toko Gunung Agung. 
9. Henocque, Y. \& Tandavanitj, S. (2008). Towards Sustainable Coastal Development in Thailand Marine and Coastal Resources Policy Green Paper. Fish for The People, Vol. 6, No. 1, 34-39.

10. Javan, J. \& Saghayi, M. (2004). Rural Tourism, Aspect of Sustainable Development. Fajr Publication, Vol. 11, No. 7, 17-32.

11. Rastghalam, M., Seidaiy, E. \& Nouri, H. (2017). The Creative Village Approach as a Tool for Creating Village Futures. Journal of Futures Studies, Vol. 21, No. 3, 35-48.

12. Muganda, M., Sirima1, A., \& Ezra, P. M. (2013). The Role of Local Communities in Tourism Development: Grassroots Perspectives from Tanzania. Journal Human Ecology, Vol. 41, No. 1, 53-66.

13. Mubyarto. (1999). Reformasi Sistem Ekonomi. Jakarta: Aditya Media.

14. Olsder, K. \& Van der Donk, M. (2006). Destination Conservaton: Protecting Nature by Developing Tourism. Amsterdam: IUCN National Committee of The Netherlands.

15. Rahayu, S., Dewi, U., \& Fitriani, K. N. (2015). Pengembangan Pariwisata berbasis Masyarakat (Community Based Tourism) di Kabupaten Kulon Progo Daerah Istimewa Yogyakarta. Laporan Penelitian Hibah Bersaing. Universitas Negeri Yogyakarta.

16. Sarstedt, M., Bengart, P., Shaltoni, A. M., \& Lehmann, S. (2017). The use of sampling methods in advertising research: a gap between theory and practice. International Journal of Advertising, 1-14. doi: 10.1080/02650487.2017.1348329.

17. Scherl, L. M. \& Edwards, S. (2007). Tourism, indigenous and local commu nities and protected areas in developing nations. in: R Bushell and P. F. J. Eagles (Eds.), Tourism and Protected Areas: Benefits beyond Boundaries, 71-88. Wallingford: CAB International.

18. Sharif, N. M. \& Lonik, K. A. T. (2017). Sustaining the Entrepreneurship in Rural Tourism Development. International Journal of Multicultural and Multireligious Understanding, Vol. 4, No. 6, 31-42.

19. Soubbotina, T. P. (2004). Beyond Economic Growth, an Introduction to Sustanaible Development. Washington D.C.: The International Bank for Reconstruction / the World Bank.

20. Tanzania Coastal Management Partnership Support Unit Coastal Tourism Working Group. (2001). TANZANIA Coastal Tourism Situation Analysis. Working Document, 5057 TCMP, $1-51$.

21. Tayebi, S.K., Jabbari, A. \& Babaki, R. (2008). Assessment of correlation between tourism and economic growth in Iran. Knowledge and Development Scientific Journal, Vol. 15, No. 24, 69-79.

22. Tenenhaus, M., Vinzi, V. E., Chatelin, Y. M. \& Lauro, C. (2005). PLS path modeling. Computational Statistics \& Data Analysis, Vol. 48, No. 1, 159-364.

23. UN. (1987). Report of the World Commission on Environment and Development 'Our Common Future'. Oslo: UN Documents.

24. UNWTO. (2013). Leading The Global Drive To Sustainable Tourism, The Sustainable Development Goals, The Global Goals for Sustainable Development.

25. Weaver, G. (1986). Tourism Development: A Potential for Economic Growth. in New Dimensions in Rural Policy: Building Upon our Heritage, Subcommittee on Agriculture and Transportation of the Joint Economic Committee, U.S. Congress, 440-444. 